\title{
Mitigating Global Climate Change: Why Are Some Countries More Committed Than Others?
}

\author{
Nives Dolsak
}

\begin{abstract}
This article analyzes factors affecting countries' commitment to mitigating global climate change within the scope of existing international institutions. The commitment level is operationalized as an ordinal variable ranging from an agreement with the international institutions (signature and ratification of the Framework Convention on Climate Change) to the actual implementation of the internationally negotiated modes of behavior (enactment of domestic environmental policies). A theoretical model of governments' decisionmaking is presented and tested for 91 countries at different levels of economic development with different domestic institutions. A given national government selects its commitment level depending on its incentives and ability to affect global emissions of greenhouse gases (GHG). An ordered logistic regression model is employed to analyze the factors affecting the levels of national commitment. Empirical analysis suggests that national commitment is significantly affected by the national government's incentives and the ability to affect the global level of GHG emissions, impacted more by the incentives than by the ability, and not affected by the aggregate levels of economic benefits.
\end{abstract}

Humankind faces a trade-off between continuing its current energy use patterns that are potentially altering the global environment and changing these patterns to minimize the risks of global climate change. If carbon dioxide emissions exceed the environment's ability to remove carbon from the atmosphere, the atmospheric concentrations of carbon dioxide increase. This increased concentration has been linked to the changes in global climate that may alter regional weather patterns and vegetation distribution and have significant health effects. ${ }^{1}$ However, global climate change risks can be decreased if humans adapt to these changes. The two approaches are not mutually exclusive. Since greenhouse gases (GHG) concentrations already have increased, adaptation will be required even if there is a drastic reduction in their current and future emissions.

This article focuses on the mitigation policies as they require explicit trade-offs between energy use and (possibly) economic growth on the one hand and reducing GHG emissions on the other. Multiple factors impact policy decisions on changing existing energy-use practices. First, there is a strong disagreement among scientists on the causes and severity of global climate change and the avenues for its mitigation. ${ }^{2}$ The grave predictions of some global climate models have not resulted in increasing policy commitment to mitigating these risks. Experiments with woody vegetation, cotton, rice, and wheat suggest that in the short run, increased carbon concentrations will have a fertilizing effect (Kramer \& Sionit, 1987), thereby partially compensating for negative environmental impacts (Baker, Allen, \& Boote, 1995; Brklacich \& Stewart, 1995; Delecolle, Ruget, Gosse, \& Ripoche, 1995; Leverenz \& Lev, 1987; Reddy, Hodges, \& McKinion, 1995; Sandenburg, Taylor, \& Hoffman, 1987; Singh \& Padilla, 1995). Further, in the long run, the human race always has benefited from increased global 
temperature level (Moore, 1997). Importantly, when the global temperature increases, its negative effects will not be uniform across the globe. For countries that face modest negative effects in the future, changing energy use imposes high costs on the current generations.

Second, the problem must be addressed at the global level. Even if policymakers in one country succeed in reducing GHG emissions, this could be offset by increased emissions in other countries. One would suspect, therefore, that the emission reduction policy of the country, which controls a larger proportion of the global emissions, will differ from a policy of a country that is capable of controlling a relatively small proportion of the global emissions.

Third, solutions need to be negotiated internationally, and countries need to accept limitations on their sovereignty. The Framework Convention on Climate Change (FCCC) formalized an international process for countries to negotiate emission targets. International institutions--the rules of behavior restraining policies of individual countries-have been developed. The global warming threat is a result of cumulative emissions over time. These rules, therefore, had to reflect the levels of differential responsibility. Thirty-four developed countries (Annex I group) accepted the primary responsibility for addressing this problem. This group was divided into: (a) the most developed countries (Annex II countries), which agreed to enact domestic policies and to provide additional international funding for developing countries to build their capacity to address global climate change issues; and (b) the countries in transition (Annex I countries in transition) that were given more time to enact domestic policies. Developing countries (non-Annex I group) were expected to report their GHG emissions and sinks provided they have sufficient financial resources (United Nations Secretariat to the Framework Convention on Climate Change, 1997).

Fourth, the trade-off exhibits conflicting preferences among and between the public and private sectors. Domestic institutions, shaping the access of different groups to the political process, could shape domestic policymaking. One would expect countries whose domestic institutions enable the policy cost-bearers to participate in the policy process to exhibit lower levels of commitment to a costly emission reduction policy.

Countries differ in their willingness to mitigate global climate change, to enact the policies to stabilize or reduce emissions, and actually to reduce emissions. Some countries have chosen the status quo and continue with their current energy use patterns. A country may agree to participate in the international efforts to mitigate global climate change and become a party to the FCCC by signing and ratifying it. Others wanting to mitigate the climate change risks may request international financial help for building domestic capabilities. An even higher commitment level is indicated by countries spending their own resources to create and submit a national report to the FCCC Secretariat. Yet a higher level of commitment is indicated by countries that publicly commit to stabilize or even reduce carbon dioxide emissions. Enacting costly domestic policies to reduce emissions ${ }^{3}$ is the highest level of commitment.

The existing levels of commitment are due partially to international negotiations that have resulted in new rules of behavior, financial contributions, and information sharing. However, countries face the same international institutions, but exhibit different commitment levels. International institutions, therefore, cannot explain variability in the commitment levels, and a focus on country-level factors is required. 
The article is organized in six sections. The immediately following section reviews the literature on international environmental cooperation, after which a theoretical model to explain the differences in the commitment levels is developed, variables of the model are operationalized, results of the empirical analysis are discussed, and implications of this article for a study of international cooperation are presented.

\section{Literature Review}

Cooperation among diverse actors is required to address the climate change risks. Three bodies of literature offer insights for understanding the different commitment levels: collective choice, international relations, and economics. The collective choice literature examines motives for cooperation, highlighting the importance of private benefits resulting from collective action as the primary motivator (Olson, 1965; Ostrom, 1990). Individuals will cooperate and adopt new institutions that restrain the individuals' behavior if the net benefits of adoption - the differences between benefits and costs-are positive. This major insight is incorporated in the model developed in this paper.

International policy decisions are made by national governments that are constrained both by the international system (third image) and domestic politics (second image) (Waltz, 1959). The third image approach to the study of international environmental cooperation examines two factors: international institutions and the size of minimum coalition required for cooperation. International institutions are conceptualized as: (a) sets of rules and practices that prescribe and constrain activity (Heller, 1996; Keohane, Haas, \& Levy, 1993); or (b) international agencies (Nietze, 1991; Richardson, 1991). These studies hypothesize how institutions may affect countries' behavior (Bernauer, 1995; Mann, 1983; Sand, 1992). Further, they examine empirically how international institutions have affected countries' behavior (Chayes \& Chayes, 1995; Keohane, Haas, \& Levy, 1993). The second body of literature employs the tools of game theory to study how the number of actors affects international cooperation. Sandler and Sargent (1995) and Maeler (1991) argue that the minimal coalition required to facilitate cooperation is much larger in the case of carbon dioxide emissions versus ozone-depleting substances. Therefore, cooperation for reducing carbon dioxide emissions is less likely.

The second image literature argues that foreign policy decisions are made by national governments that are constrained by national political and economic factors (Chayes \& Chayes, 1993; Cowhey, 1993; Sprintz \& Vaahtoranta, 1994; Young, 1989) and on characteristics of actors within countries (Benedick, 1991; Boehmer-Christiansen \& Skea, 1991; Mitchel, 1995; Oye \& Maxwell, 1995).

In economic studies, the foci of analysis usually are policy instruments that are most effective in facilitating cooperation (Barrett, 1992; Cline, 1992; Frankhauser, 1995; Grubb, 1996; Kawashima, 1996; Nordhaus, 1991; Paterson, 1996). These studies indicate that side payments may be necessary for international cooperation. Grubb (1989) and Mohr (1991) argue that developing countries may require side payments to limit their GHG emissions. Toll (1995) argues, however, that strictly in economic terms developing countries would have to take initiative and persuade and/or compensate the developed countries, as their economies are significantly more sensitive to climate changes. If the latter holds, international cooperation to mitigate global climate change is not likely to 
increase, as developing countries are hardly capable of providing side payments to developed countries.

\section{Factors Affecting Commitment Levels}

In this section, I present an "incentive-ability" model that is predicated on the following assumptions: (a) national governments are rational decisionmakers; (b) they compare aggregate economic benefits and costs of the commitment; (c) individuals constituting the national government also follow their respective political goals; (d) the benefits of mitigating global climate change depend on the global reductions of carbon dioxide concentrations and therefore can be affected only partially by a given country's policy; and (e) it is very difficult to enforce the negotiated targets within the FCCC provisions. Countries, therefore, rather than assuming complete compliance of others, consider how much of the outcome is under their control.

The logic of the incentive-ability model is as follows. A national government calculates the benefits and costs of mitigating global climate change. If the benefits exceed the costs, the government has an incentive to mitigate. However, a country that reduces its emissions will not benefit from its reductions unless global emissions do not increase (remain the same or decrease). Therefore, a national government considers the costs and benefits of its action as well as the probability that the global concentrations of carbon dioxide will not increase. Then, a national government will commit to a costly policy only if it has some assurance that the global level of emissions actually will decrease. Since international environmental agreements are very difficult to enforce, the fact that countries have negotiated emission targets offers only a partial assurance. A country's government is more capable of affecting the global GHG emissions if the country either is a large emitter or it can induce other countries (by bribing or by threatening) to commit to mitigating. The argument is presented schematically in Table 1.

\section{Table 1}

National Commitment as a Function of Incentives and Ability to Affect Global Emissions

\begin{tabular}{llll} 
& & \multicolumn{2}{c}{ Positive Net Benefits } \\
& Low & High \\
Ability to affect & Low & & Medium \\
global emissions & High & Medium & High \\
\hline
\end{tabular}

A national government with high net benefits of climate change mitigation and high ability to affect the global emissions (the southeast cell) should exhibit the highest commitment level. A national government with low net positive benefits of global cooperation and low ability to affect the global emissions (the northwest cell) is predicted to exhibit the lowest commitment level. A government with low net benefits and high ability to affect the global emissions (the southwest cell) and a government with high net benefits and low 
ability to affect the global emissions (the northeast cell) would exhibit medium levels of commitment.

Benefits of mitigating global climate change can be conceptualized in two ways: (a) economic benefits to climate-sensitive activities in the country (for example, agriculture, forestry, and fishing); and (b) political benefits of the commitment-the national government can take credit (domestically and internationally) for addressing a salient environmental concern. Uncertainty related to the occurrence and spatial distribution of global climate change, its consequences for the climate-sensitive economic activities, and their monetary evaluation significantly complicate the estimation of the aggregate economic benefits. An important concern, then, is: How do these benefits affect the national governments' decisions if they are so uncertain and their estimation so difficult? Needless to say, this uncertainty affects any kind of analysis of this problem and is not limited to quantitative analysis.

The second type of benefits pertains to political recognition (domestic and international) given to the government for its high commitment. In a democratic country, political leaders are affected by domestic public opinion (Russett, 1993). If there is a public concern about environmental issues and if voters are favorably inclined to addressing them, the commitment may bring political benefits to the leaders. One needs to be aware, however, that public concern is not uniform - there may be a higher level of concern about local environmental issues and a weaker concern about international issues. However, wide public support is not required for the commitment. Sometimes, a strong, publicized concern of some environmental organizations is sufficient to exert pressure on the national government. Differences in the levels of national commitment, therefore, may be attributed to the degree of democratization in the country and the extent to which the public is concerned about the environment.

Public opinion is not always pro-environment, especially when environmental policies create winners and losers (Rowell, 1997; Vaughn-Switzer, 1997). The question, then, is whether the winners and losers are organized (Oye \& Maxwell, 1995) and how they access the decisionmakers (Crepaz, 1995). If the winners have better access, the political benefits to decisionmakers of mitigating exceed the costs. If the losers have better access, the contrary holds.

The commitment costs also can be conceptualized in two ways: (a) the economic costs of the commitment (for example, higher prices of fossil fuels leading to decline in profits and the migration of economic activity abroad); and (b) political difficulties that a national government may face when enacting these policies. The economic costs differ among countries due to differences in energy resources being used, energy pricing policy, levels of energy efficiency, and economic structure. Countries relying predominantly on coal for meeting their energy demand may not be willing to adopt any action because coal combustion, in comparison with other fuels, emits more carbon per unit of energy. Major oilproducing countries also may not support mitigation efforts because this policy may reduce their revenues. Countries depending predominantly on fossil fuels, therefore, may oppose actively any action. The data indicate that Organization of Petroleum Exporting Countries (OPEC) members exhibit low commitment levels: Most of them signed and ratified the FCCC, five of them are receiving international funding to increase their capacities to mitigate global climate change, but none of them reported their carbon dioxide emissions and sinks nor committed to reducing their emissions. 
Norway presents a striking contrast to the behavior of the OPEC countries. Even though it is an important oil exporter, it is highly committed to reducing its GHG emissions. It has increased carbon dioxide taxes (the increase, however, was offset by an elimination of the basic tax rate for oil) and has initiated and partially funded multiple international projects to reduce energy-related carbon dioxide emissions including projects in Mexico and Poland (International Energy Agency, 1994). The reasons for Norway's high commitment may be found in weak objection of the oil industry. Norway's industry is expected to grow in the environmentally friendlier fuels--natural gas-and not significantly increase its oil production (International Energy Agency, 1994). Further, Norway exhibits a fairly high level of environmental concern (Dunlap, Gallup, \& Gallup, 1993).

Domestic political institutions also may increase the commitment costs. A national government may face a strong opposition from actors whose profits may decline as the result of the climate change policy. Organized policy losers may exert political pressure on the government (the level and organizational unit to which they have access) and try to prevent the policy enactment. A strong state-the one more able to impose losses on economic actors (Krasner, 1978) - faces fewer difficulties in enacting high-cost environmental policies. State strength should not be understood as the scope of governmental activities. A government that regulates a larger proportion of national economic activity is not necessarily stronger, as regulatory agencies may be captured by private interests (Krasner, 1978). Therefore, it is necessary to focus on the access that private actors have to policy formulation and adoption. In some political systems, new policies are prepared cooperatively by governmental agencies and industry (for example, Britain). The policies are based on voluntary action of industry and usually result in lower standards for the industry. In more pluralistic systems that are more open to the public and more conflictual (for example, the United States), substantially higher standards can be set by regulatory agencies. The more stringent standards, however, do not necessarily lead to superior outcomes, and it is not obvious which political system protects the environment better. Vogel (1986) compares the effectiveness of an environmental policy in Great Britain and the United States that required a major change in electricity generation to reduce its environmental effects. He points out that both political systems have achieved comparable levels of environmental quality even though they experienced different levels of cooperation between the industry and the government.

After the new regulations are finalized, they are proposed for adoption. The ability of the national government to impose losses on powerful groups again depends on domestic institutions. The paper focuses on two domestic institutions regulating separation of power: (a) between executive and legislative branch--presidential versus parliamentary systems; and (b) among different levels of government-unitary versus federal systems. There is no simple answer regarding the effects of a presidential versus parliamentary system. Parliamentary systems have stronger party discipline and greater centralization of legislative power, but they also have a greater centralization of accountability. They are considered to be more capable of removing veto points and therefore more capable of imposing losses onto powerful private actors. One could argue, however, that the greater accountability exposes the national government to the criticism of the policy losers and therefore makes them more reluctant to adopt such policies (Weaver \& Rockman, 1993). In federal systems, power is shared between national and subnational governments. If these levels have substantial autonomy, the 
national government has to negotiate a policy adoption. The veto of subnational governments is important in the case of climate change, where the policy costs are explicit and perceived at the local level, whereas the benefits of policy may occur only in the distant future to people around the globe and not necessarily to the voters in the subnational unit. This suggests that unitary governments will be more capable of imposing losses on powerful actors than federal governments (Vogel, 1993; Weaver \& Rockman, 1993; Yandle, 1989).

The above discussion indicates that the actual effects of domestic institutions on the capability of the government to impose losses, the strength of the effects, and their direction are unclear. Although empirical analyses of policies having important distributional effects indicate that variables other than domestic institutions impact government effectiveness (Feigenbaum, Samuels, and Weaver, 1993; Milner, 1993), this article suggests that countries with parliamentary systems are more likely to commit to higher levels of climate change mitigation than are ones with presidential systems.

The third important variable affecting the national commitment is the country's ability to affect global emissions. A country can benefit from its reductions of emissions only if other countries also cooperate. In the case of a unilateral mitigation, the reduction of emissions in one country may be followed by a shift of carbon-intensive activities to less-committed countries. As a result, the total global emissions would remain the same or perhaps even increase. In this case, the global climate change risks are not reduced, and in turn the climatesensitive activities do not benefit from the country's mitigation efforts. Therefore, the greater the government's ability to affect the global GHG emissions, the more likely it will commit to mitigating climate change. The ability to affect global emissions depends on two factors. First, the countries that are large emitters know that if they stabilize their emissions, the global level of emissions will be affected significantly. For example, in the middle of the 1990s, the United States accounted for about $24 \%$ of world energy-related carbon emissions. If the U.S. government enacts a rigorous environmental policy reducing carbon dioxide emissions, one-fourth of current global emissions is addressed. If, on the other hand, a small emitter like Austria, which accounted for about $0.25 \%$ of world emissions, enacts rigorous domestic policy, its government has no assurance of what will happen to the remaining $99.75 \%$ of the emissions. Second, a country will have more control over global emissions if it can affect the behavior of others. A national government can affect behavior of other governments by a variety of means, including military power and economic incentives/sanctions. The use of military power and international economic sanctions is substantially limited. One could argue, however, that wealthier economies are likely to be able to affect the behavior of other governments through international financial agencies, where their influence is proportional to their contributions to the agency's budget (Heller, 1996; Hudec, 1996).

\section{Operationalization of the Model}

\section{National Commitment to Mitigating Global Climate Change}

The ultimate objective of the FCCC is "to achieve stabilization of greenhouse gas concentrations in the atmosphere at a level that would prevent dangerous anthropogenic interference with the climate system" (United Nations Framework Convention on Climate Change, 1993, p. 194). To achieve this goal, national negotiators have set a series of intermediate goals, such as submitting 
national reports on GHG emissions and sinks, reducing the emissions and increasing the sinks, sharing financial burden of these activities, and helping developing countries (non-Annex I countries) achieve some initial targets. Measuring atmospheric GHG concentrations could indicate whether the ultimate goal is being attained. However, since the FCCC's ultimate goal was to stabilize the GHG concentrations in the long term, measuring the concentrations at this point (only 6 years after the FCCC) would tell little about the goal attainment. Further, measuring the global concentrations would tell nothing about what individual countries have achieved. Therefore, other measures of goal attainment are required that are based on intermediate goals of the negotiations.

To achieve the ultimate goal of stabilizing GHG concentrations, countries have negotiated multiple intermediate targets of the FCCC. The expected attainment of these targets is differentiated by groups of countries: Annex I countries (the most developed countries and the "countries in transition"-East and Central European countries) and non-Annex I countries (developing countries). The most developed countries have agreed in the FCCC to: (a) stabilize their emissions of carbon dioxide at the 1990 levels by the year 2000; (b) adopt national policies to achieve this goal; (c) submit a national report on the sources and sinks of their GHG; and (d) provide the "new and additional financial resources" that would enable developing countries to submit their national reports. Countries in transition also have agreed to stabilize their emissions, but they were granted more flexibility. Non-Annex I countries have agreed to submit reports on their carbon dioxide sources and sinks. Since the submission of such data depends on the availability of financial resources, these countries are eligible to apply for international financial help (Grubb, 1996; United Nations Framework Convention on Climate Change, 1993).

Building on these targets and suggestions of Keohane, Haas, and Levy (1993) and Bernauer (1995), I create an ordinal variable measuring the national commitment to addressing the risks of global climate change (COMM). The higher values of the variable represent higher commitment levels. The commitment levels are presented in Table 2.

The signature and ratification of the FCCC represent the first two commitment levels (values 1 and 2). The values 3, 4; and 5 indicate that a country is in the process of building national capacity to comply with the FCCC. The values 6,7 , and 8 indicate that a country already has developed national capacity to comply with the FCCC and has made a public commitment to mitigate global climate change. The value 9 is assigned to countries that have enacted costly national policies to achieve the declared goals; that is, enacted or significantly increased energy or carbon taxation after the FCCC.

Most countries have attained multiple goals, such as having signed and ratified the FCCC and started building their domestic capacities to comply with the FCCC. Many countries already have built their domestic capacities and submitted their national reports. For each country, I code the dependent variable with the highest level that a country has attained. For example, the United States has signed and ratified the FCCC, built its capacities to start addressing the global climate change risks, submitted the national report, and formally agreed that it would meet the Rio emission target. Therefore, I code the U.S. commitment level as 7 (meeting the Rio emission target). 


\section{Table 2}

\section{National Commitment Levels}

1 A country has signed the FCCC.

2 A country has ratified the FCCC.

3 A country is a recipient of international aid available to the parties of the FCCC.

4 A country is a recipient of international aid, and the project has an explicit goal of submitting a national communication.

5 A country is a recipient of international aid, and the project has an explicit goal of implementing an emission reduction or sink enhancement technology.

6 A country has submitted a national report and/or has prepared a national plan.

7 A country has agreed formally to the Rio emission target-stabilization of emissions at the 1990 level by 2000 , by stating this in its national report.

8 A country has agreed formally to a more ambitious target (i.e., the Toronto emission reduction target) by stating this in its national report.

9 A country has enacted energy or carbon taxes.

\section{The Benefits of Mitigating Global Climate Change}

A national government considers both the aggregate economic benefits and the political support it can generate. The aggregate benefits have been estimated by economists (Cline, 1992; Frankhauser, 1995; Nordhaus, 1991; Toll, 1995). These estimates, however, are made at the global level and not at the level of national economies. Estimates at the national level are available only for selected countries. Mendelson, Morison, Schlesinger, and Andronova (1997) estimate that economies of Africa, Asia, Latin America, and Oceania will bear costs, whereas North America and Europe will benefit, from climate change. Some estimates are available for developing countries (El-Shaer, Eid, Rosenzweig, Iglesias, \& Hillel, 1996; Matarira, Mwamuka, \& Makadho, 1996; Mizina, Eserkepova, Pilifosova, Dolgih, \& Gossen, 1996) and for particular sectors, such as forests (Dixon, Krankina, \& Kolbak, 1996; Grozev, Alexandriv, \& Raev, 1996; Mata, 1996).

Since the data on aggregate economic benefits are not available for a large sample of countries, this article uses an indicator measuring economic sensitivity to the risks of increased GHG concentrations. Toman and Bierbaum (1996) argue that the higher the level of human involvement in a sector the less sensitive the sector is to climate changes. Industry and services are less sensitive, whereas agriculture, water resources, and managed forests are more sensitive. One then could argue that countries with larger proportions of gross domestic product (GDP) originating in climate-sensitive sectors would be more committed to mitigating global climate change. This article uses the percentage of GDP that originates in the climate-sensitive sectors (agriculture, forestry, and fisheries). However, in some geographical areas with some types of vegetation, the changes in carbon dioxide concentrations and the resulting temperature, precipitation, and evapotranspiration changes actually may increase vegetation growth. The used indicator, however, does not reflect these characteristics of local environment. Further, it could be argued that the longer the coast, the more sensitive the country 
is to the potential climate changes and sea level rise. This measure, however, did not have a statistically significant effect in my analysis.

A national government also considers the effects that the policy enactment may have for its political survival. One could argue that more democratic countries with higher levels of environmental public concern are more likely to exhibit higher commitment levels. ${ }^{4}$ I am not aware of any indicator of public concern about global climate change available for a large number of countries. Some national poll results exist, but they are not comparable. Internationally comparable data are available only for a selected group of countries (Dunlap et al., 1993; Inglehart, 1995). The question is: What can be assumed about public opinion in the countries for which data are not available? Although economists have developed several methods for estimating the "demand" for environmental quality (Braden, Kolstad, \& Miltz, 1991), they do not explain how higher available income would affect the demand.

This article operationalizes the measure of environmental concern based on the work on postmaterialism, in which individuals value clean environment more as their economic security increases (Inglehart, 1995). On the other hand, one could argue that individuals in countries with lower economic security depend more on income from the primary sector, especially from agriculture. Since their income is highly sensitive to climate change, they may place a high value on a clean environment. Inglehart makes his argument based on longitudinal studies. I assume that the same trend can be observed across countries with varying levels of economic development (GDP per capita). In my empirical analysis, I therefore use data on GDP per capita (GDP95CAP) as the proxy to estimate the effect of the level of public concern on national commitment.

\section{The Costs of Mitigating Global Climate Change}

Two cost estimation approaches have been used in the economic literature: the top-down and the bottom-up approach. The top-down macroeconomic models estimate the costs of stabilizing emissions of carbon dioxide at the 1990 level will amount to 0.5-0.6\% GNP loss (Frankhauser, 1995). The bottom-up studies, estimating project investment costs (Frankhauser, 1995; Global Environmental Change Report, 1993), suggest that large emission reductions can be achieved at little or no cost. The available cost estimates have two important shortcomings. First, they pertain to a small group of countries (Barbier, Burgess, and Pearce, 1990; Rose, 1992). Second, even for these countries, they are made for different reduction scenarios and therefore are not directly comparable.

Since data do not exist on costs of commitment and policy enactment, I use proxies capturing the importance of energy for the living standard of the population. If the lifestyle is energy-intensive (high total primary energy supply per capita, TPESCAP), reduction of carbon dioxide emissions would be costly. Countries with a high-energy supply per capita therefore are expected to exhibit low commitment levels. However, the effect is not as clear as it seems. Highenergy supply per capita is just a mirror image of low energy efficiency. Low energy efficiency could reflect low levels of past commitment to clean environment and high political costs of global climate change policy in this country. On the other hand, it could imply that many low-cost or zero-cost options to improve energy efficiency have not been implemented yet and that high commitment to mitigating climate change would not necessarily face high 
economic costs. It is therefore not clear which direction of the effects we should expect.

Further, if the economy depends on energy exports for earning hard currency, then the government is less likely to enact rigorous environmental policy targeted at the energy sector. To capture this relationship, I use a dichotomous variable (NEXPENER). The variable has value 1 if the country is a net energy exporter or 0 if it is not. ${ }^{5}$

In addition to the aggregate economic costs, a government also considers the political difficulties it may face when enacting a rigorous environmental policy and imposing significant costs on economic actors. A government's ability to impose these costs depends on characteristics of the domestic political system. I hypothesize that parliamentary systems would have fewer difficulties in imposing costs on economic actors. I use a dichotomous variable measuring whether a country has a parliamentary system or not (PARL). ${ }^{6}$

\section{The Ability to Affect Global Emissions}

A national government that can affect global emissions is more likely to commit to mitigating global climate change. Governments can affect the global emissions level in two ways. First, if a country accounts for a large share of the global emissions (EC92CPE), then the national government is in control of a large proportion of the global environmental problem. For example, since the United States accounted for about $24 \%$ of the current world energy-related carbon emissions in the mid-1990s, the policies of the U.S. government could have significant impact on the global emission level.

Second, governments can affect the decisions of other governments by offering incentives. Economic adjustment programs applied in several developing countries indicate that the lenders dictate the terms of loan rescheduling as well as the terms of new loans. These terms increasingly are affecting the environmental policies of loan-takers. Debt-for-nature projects indicate similar trends. If these routes are used by the national governments of lenders to affect the GHG policy of borrowers, we should see higher commitment levels of the lenders. I measure the economic power of a country by its share in the total world GDP (GDP92CPE).

\section{The Empirical Results}

This section examines the results of the empirical analysis of the incentive-ability model, based on data for 91 countries. Since the dependent variable is ordinal, an ordered logistic regression model is employed (Long, 1997). The independent variables used in this analysis are explained in detail in Appendix A. The descriptive statistics of the independent variables are presented in Table 3.

The indicator of countries' commitment levels (COMM) was regressed on the variables measuring the estimated benefits of committing (GDP95CAP), the costs (TPESCAP, NEXPENER), the domestic institutions (PARL), and the country's ability to affect global emissions (GDP92CPE, EC92CPE). The estimated regression coefficients are presented in Table 4.

This article's theoretical model is mostly supported by the empirical analysis. The hypothesized effect of the aggregate economic benefits of mitigating global climate change, measured with the proportion of GDP originating from climate-sensitive activities, was not supported by the empirical analysis. The reasons probably lie in the lack of measures of benefits of mitigating global climate change available at a national level. I have used a proxy indicator 
Table 3

Descriptive Statistics of the Variables $(n=91)$

\begin{tabular}{lcccc}
\hline Variable & Mean & $\begin{array}{c}\text { Standard } \\
\text { Deviation }\end{array}$ & Minimum & Maximum \\
COMM & 4.48 & 2.28 & 0.00 & 9.00 \\
ANNEXII & 0.25 & 0.44 & 0.00 & 1.00 \\
ANNEXITR & 0.04 & 0.21 & 0.00 & 1.00 \\
GDP95CAP & 8.45 & 7.71 & 0.70 & 27.50 \\
NEXPENER & 0.40 & 0.49 & 0.00 & 1.00 \\
PARL & 0.44 & 0.50 & 0.00 & 1.00 \\
GDP92CPE & 1.00 & 3.11 & 0.06 & 24.64 \\
EC92CPE & 0.88 & 2.88 & 0.00 & 23.90 \\
TPESCAP & 2.14 & 2.60 & 0.02 & 12.98 \\
\hline
\end{tabular}

\section{Table 4}

\section{Estimated Unstandardized Coefficients for Regression of National Commitment on Benefits, Costs, and Ability}

\section{Variable}

ANNEXII

ANNEXITR

GDP95CAP

NEXPENER

PARL

GDP92CPE

EC92CPE

TPESCAP

$\mathrm{chi}^{2}$

Prob $>\mathrm{chi}^{2}$

Pseudo R ${ }^{2}$

\section{Regression Coefficients}

$$
\begin{gathered}
4.010^{* * *} \\
(3.076) \\
2.391 \\
(1.596) \\
.221^{* *} \\
(2.442) \\
-1.256^{* * *} \\
(-2.856) \\
1.047^{* *} \\
(2.329) \\
-0.362^{* *} \\
(-2.579) \\
0.338^{* *} \\
(2.480) \\
-0.424 * * \\
(-2.750) \\
93.76 \\
\text { df }=8 \\
0.0000 \\
0.2493
\end{gathered}
$$

Notes: $\quad n=91$.

Numbers in parentheses are $\mathrm{z}$ - statistics of beta.

${ }^{*} p<0.10,{ }^{* *} p<0.05 .{ }^{* * *}$, and $p<0.01$ (two-tailed tests).

measuring the proportion of a country's GDP originating in climate-sensitive activities (agriculture, forestry, and fisheries). This indicator does not encompass 
the fact that agriculture and forestry in some countries actually may benefit from the increased carbon dioxide concentrations. However, the other measure of benefits has a statistically significant effect; national governments are more likely to commit to higher levels if this action may bring public support at the time of election. This indicates that in spite of organized pressure from the policy losers (for example, fossil fuel industry and/or organized labor), national governments take into consideration the diffused and not necessarily organized opinion of policy winners.

The employed measures of costs were even better predictors of national commitment levels. Two variables measuring costs have statistically significant effects on national commitment. Net exporters of energy (NEXPENER) exhibit lower levels of national commitment, holding other variables constant, and countries with higher per capita energy supply (TPESCAP) exhibit lower commitment levels. This suggests that energy-intensive lifestyles impact the trade-offs between energy and environment more than do positive effects of potential cost savings resulting from decreasing energy consumption. Contrary to expectations and empirical results of other scholars (Feigenbaum et al., 1993; Weaver \& Rockman, 1993), the empirical data also support the hypothesis that the domestic political system affects what national governments decide when presented with the environment/energy trade-off. National governments in parliamentary systems (PARL) face lower political costs of environment/energy trade-offs than in presidential systems.

The empirical results about the role of a country's ability to affect the global emissions are mixed. On the one hand, the indicator measuring the country's share of global emissions (EC92CPE) has a statistically significant effect on the national commitment levels; the larger the country's share of the world carbon emissions, the higher the commitment level. This finding supports the theoretical predictions of game theory. On the other hand, the empirical analysis does not support my hypothesis that the greater the economic power (defined as the country's proportion of the world GDP-GDP92CPE) the higher the commitment.

\section{Predicted Levels of National Commitment Using the Incentive- Ability Model}

I have argued that the countries with high net benefits of addressing the global climate change risks and high ability to affect the global level of carbon dioxide emissions (southeast cell in Table 1) will have the highest national commitment levels. Countries with low net benefits and low ability to affect the global level of emissions were expected to have the lowest national commitment levels (northwest cell, Table 1). The countries of the other two groups would exhibit commitment levels somewhere in between these two extremes. The probabilities of achieving a particular level of national commitment, estimated with the presented theoretical model, support my hypotheses. The estimated probabilities are presented in Figure 1 (see Appendixes B and C for a detailed explanation).

Countries in the southeast cell of Table 1 have exhibited the highest levels of commitment. At the minimum, these countries have committed to the Rio stabilization target (the probabilities of each of the commitment levels below this one are negligible--less than $1 \%$ ). A large majority of these countries $(88 \%)$ have achieved the highest commitment level-they enacted national policies. As 
hypothesized, the countries in the northwest cell have exhibited the lowest levels of commitment. A negligible proportion (less than $1 \%$ ) of these countries have submitted their national reports or exhibited a higher level of commitment. Most of these countries (43\%) have applied for international funding to build national capacity to mitigate global climate change, but only $11 \%$ have applied for international funding with the goal of preparing national communications.

Further, the empirical results indicate that the effects of incentives on national commitment are stronger than the effects of the ability to affect global emissions. Moving from the column of low net benefits (left) to the column of high net benefits (right) indicates drastically increased commitment levels. For example, moving from the northwest cell to the northeast cell increases the probability that a country at least will submit the national communication or achieve any higher commitment level from 0.012 to 0.992 (the same probabilities increase from 0.037 to 0.997 when moving from the southwest to the southeast cell). On the other hand, increasing the ability to affect global emissions (an increase in the country's share of global carbon dioxide emissions), as represented in the shift from the top row to the bottom row, does not increase the probability of the highest levels of commitment nearly as much. For example, moving from the northwest cell to the southwest cell increases the probability that a country

\section{Figure 1}

\section{Predicted Probabilities of National Commitment Levels}
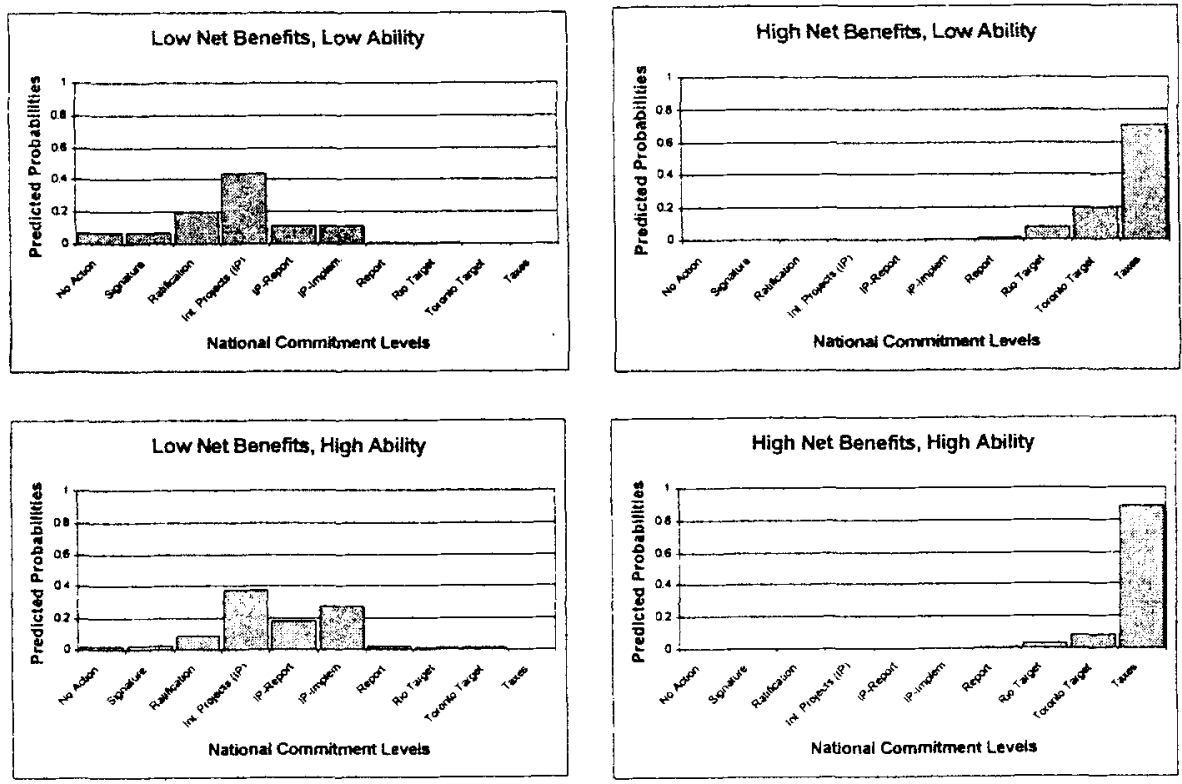

will at least submit the national communication or exhibit a higher commitment level from 0.012 to 0.037 (the same probabilities increase from 0.992 to 0.997 
when moving from the northeast to the southeast cell) (see Appendix B). The incentives - the costs and the benefits-have a much stronger effect on the national commitment level than the ability to affect global emissions. This suggests that the country-level variables (the second image) explain the commitment levels significantly better than the systemic variables (the third image).

\section{Conclusions}

This article presents a theoretical model that explains factors affecting national commitment to provide an international public good-global climate change risk mitigation. It employs a rigorous quantitative analysis to test the model with empirical data from 91 countries. National commitment to mitigating risks of global climate change is measured with an ordinal variable, ranging from an agreement with the international institutions (signature and ratification of the FCCC) to actual implementation of the internationally negotiated modes of behavior (enactment of domestic environmental policies).

Developing a measure of compliance with international institutions is the first major contribution of this paper. International institutions - rules restraining energy and environmental policies of individual countries-have evolved significantly in the last two decades. The actual effects of international institutions, however, are only beginning to be examined empirically. Effectiveness of international institutions is very difficult to measure, as we do not have the luxury of the controlled experiment-it is not known what would have happened had the institutions not been developed. This article offers one potential approach to measuring effectiveness of international institutions.

I examine propositions of two different schools of international relations. One school argues that domestic factors affect foreign policy (the second image theories), while the other school (the third image theories) argues that international cooperation can be explained by the characteristics of the international system, such as existence of international institutions and the ability of an individual country to affect the collective outcome. The empirical results suggest that international institutions cannot explain variation in country-level commitment. This does not mean that they did not have any effect. Clearly, without international institutions, countries most likely would exchange less information on climate change, and in turn have a poorer understanding of global climate change. Consequently, fewer countries would be willing to address the energy/environment trade-off.

International institutions, however, cannot explain variations in the commitment levels among countries. To address this issue, I proposed an incentive-ability model, arguing that national commitment levels are affected by both domestic incentives for mitigating the global climate change risks and the country's ability to affect the global level of carbon dioxide emissions. The empirical results suggest that the domestic costs of contributing to the international public good (both economic and political) are more important than the ability to affect its aggregate levels. Thus, efforts to address this global environmental problem would be most productive if they were focused on reducing costs of emission reductions rather than on finding ways to increase the transparency of countries' actions. 
One potential venue of future analysis would be to examine whether strategic negotiation behavior actually is used by some governments as an exercise of negotiating power (independent variable). I explicitly exclude negotiation behavior from my measure of national commitment (dependent variable). This is because it is not clear whether active participation in negotiations actually represents higher commitment to provision of the international public good or just strategic behavior-an attempt to dictate the international institutions. For example, how could one categorize Resolution 98, passed by the U.S. Congress? The resolution calls on the United States to reject any climate change treaty that does not include developing countries (Wirth, -1997). The fact that the Clinton Administration made a formal proposal can be seen as an indicator of national commitment. On the other hand, one could argue that the U.S. proposal was really a step back, because it conditions its national commitment on the national commitment of developing countries, contrary to the FCCC, which gave special flexibility to these countries. The latter explanation seems to be stronger, given that the Bush Administration used this argument to withdraw from the Kyoto Protocol. It would be productive, however, to examine the same behavior as an independent variable-the exercise of negotiation power.

This article suggests that it is important to develop better indicators of consequences of global climate change. Costs and benefits of global climate change feature in all policymaking decisions. Recent developments in environmental policymaking in the United States require every policy decision explicitly to estimate costs and benefits. Other countries may not have such explicit requirements, but costs and benefits still may be considered implicitly.

The results of this article add to the theoretical debate about the role of domestic institutions on energy policy and environmental policy. The empirical results suggest that domestic institutions do play a role both in domestic and international environmental policy processes, contrary to Weaver and Rockman (1993) and Feigenbaum et al. (1993). Parliamentary countries are more likely to enact costly environmental policies. It is possible, however, that the observed positive effect of parliamentary versus presidential systems may have resulted from the fact that the presidential systems experienced a split between the executive and the legislative branches along the party lines, for which this article does not control.

$* * *$

Nives Dolsak received a joint Ph.D. from the School of Public and Environmental Affairs and the Department of Political Science, Indiana University, Bloomington. She is currently a post-doctoral research associate with Workshop in Political Theory and Policy Analysis, Indiana University, Bloomington.

\section{Notes}

I thank Daniel Benjamin, Joe Bial, Sara Colburn, Riley Dunlap, David Gerard, Peter Haas, Kerry Krutilla, Mary Matthews, Elinor Ostrom, Detlef Sprintz, Rick Stroup, Matthew Potoski, Aseem Prakash, Paul Turner, Marc Zacher, the participants of the "Cooperation within Regimes" panel at the International Studies Association conference, March 1998, and the anonymous reviewer for their comments. This research was supported financially by the Political Economy Research Center, Bozeman, Montana and the Center for the Study of Institutions, Populations and Environmental Change, Indiana University, Bloomington.

${ }^{1}$ There are multiple gasses associated with the risks of climate change. Due to the difficulties in estimating methane and nitrous oxide emissions (Global Environmental Change Report, 
1992), most policies focus on carbon dioxide (International Energy Agency, 1994, 1996a). Importantly, carbon dioxide emissions related to commercial energy use account for $57 \%$ of GHG emissions (Policy Implications of Greenhouse Warming, 1991).

${ }^{2}$ See, for example, Balling, 1992; Climate Change, 1995; Intergovernmental Panel on Climate Change, 1995; Global Warming Experiment, 1995.

${ }^{3}$ Global concentrations of carbon dioxide can be reduced by reducing emissions and/or removing carbon dioxide from the atmosphere. International mitigation projects to store carbon in growing biomass, thereby removing it from the atmosphere, have been financed by developed countries and hosted by developing countries. Areas that are set aside to store carbon have to preserve the vegetation cover and cannot be developed. Thus, this policy shifts the energyenvironment trade-off to a more general development-environment trade-off.

"The effect of democracy level was not statistically significant.

${ }^{5}$ Higher reliance on coal or other fossil fuels, which would imply higher costs of emission reductions, was not statistically significant.

${ }^{6}$ I also examined whether federal governments are less likely to exhibit higher commitment levels than unitary ones, but found no statistically significant effect.

\section{References}

Balling, R. C., Jr. (1992). The heated debate: Greenhouse predictions versus climate reality. San Francisco, CA: Pacific Research Institute for Public Policy.

Baker, J. T., Allen, L. H., Jr., \& Boote, K. J. (1995). Potential climate change effects on rice: Carbon dioxide and temperature. In C. Rosenzweig, G. A. Peterson, D. M. Kral, \& M. K. Viney (Eds.), Climate change and agriculture: Analysis of potential international impacts (pp. 31-50). Special publication No. 59. Madison, WI: American Society of Agronomy.

Barbier, E. B., Burgess, J. C., \& Pearce, D. W. (1990). Slowing global warming: Options for greenhouse gas substitution. London: London Environmental Economics Centre.

Barrett, S. (1992). "Acceptable" allocations of tradable carbon emission entitlements in a global warming treaty. In United Nations Conference on Trade and Development, Combating global warming: Study on a global system of tradable carbon emission entitlements (pp. 85-113). New York, NY: United Nations Conference on Trade and Development.

Benedick, R. E. (1991). Ozone diplomacy: New directions in safeguarding the planet. Cambridge, MA: Harvard University Press.

Bergesen, O. H., \& Parmann, G. (Eds.). (1996). Green globe yearbook of international co-operation on environment and development. Oxford: Oxford University Press.

Bernauer, T. (1995). The effect of international environmental institutions: How we might learn more. International Organization, 49(2), 351-377.

Boehmer-Christiansen, S., \& Skea, J. (1991). Acid politics: Environmental and energy policies in Britain and Germany. Cambridge: Belhaven Press.

Braden, J. B., Kolstad, C. D., \& Miltz, D. (1991). Introduction. In J. B. Braden \& C. D. Kolstad (Eds.), Measuring the demand for environmental quality (pp. 3-16). Amsterdam: Northern Holland.

Brklacich, M., \& Stewart, R. B. (1995). Impacts of climate change on wheat yields in the Canadian prairies. In C. Rosenzweig, G. A. Peterson, D. M. Kral, \& M. K. Viney (Eds.), Climate change and agriculture: Analysis of potential international impacts (pp. 147-162). Special publication no. 59. Madison, WI: American Society of Agronomy.

Central Intelligence Agency. (1997). The world fact book [On-line]. Available: http://www odci.gov/cia/publications/nsolo/Fact book.

Chayes, A., \& Chayes, A. H. (1993). On compliance. International Organization, 47(2), 175-205.

Chayes, A., \& Chayes, A. H. (1995). The new sovereignty. Cambridge, MA: Harvard University Press.

Cline, W. R. (1992). The economics of global warming. Washington, DC: Institute for International Economics.

Cowhey, P. F. (1993). Domestic institutions and the credibility of international commitments: Japan and the United States. International Organization, 47(2), 299-326.

Crepaz, M. M. L. (1995). Explaining national variations of air pollution levels: Political institutions and their impact on environmental policy making. Environmental Politics, 4(3), 391-414.

Delecolle, R., Ruget, F., Gosse, G., \& Ripoche, D. (1995). Possible effects of climate change on wheat and maize crops in France. In C. Rosenzweig, G. A. Peterson, D. M. Kral, \& M. K. Viney (Eds.), Climate change and agriculture: Analysis of potential international impacts (pp. 241-258). Special publication no. 59. Madison, WI: American Society of Agronomy.

Dixon, R. K., Krankina, O. N., \& Kolbak, K. I. (1996). Global climate change adaptation: Examples from Russian boreal forests. In J. B. Smith, N. Bhatti, \& G. V. Menzhulin (Eds.), Adapting to climate change: An international perspective (pp. 359-373). New York, NY: Springer. 
Dunlap, R. E., Gallup, Ir., G. H., \& Gallup, A. M. (1993). Health of the planet: Results of a 1992 international environmental opinion survey of citizens in 24 nations. Princeton, NJ: The George H. Gallup International Institute.

El-Shaer, M. H., Eid, H. M., Rosenzweig, C., Iglesias, A., \& Hillel, D. (1996). Agricultural adaptation to climate change in Egypt. In J. B. Smith, N. Bhatti, \& G. V. Menzhulin (Eds.), Adapting to climate change: An international perspective (pp. 109-127). New York, NY: Springer.

Europa World Year Book. Volume I and II. (1997). London, England: Europa Publications Limited.

Feigenbaum, H., Samuels, R., \& Weaver, R. K. (1993). Innovation, coordination, and implementation in energy policy. In R. K. Weaver \& B. A. Rockman (Eds.), Do institutions matter? Government capabilities in the United States and abroad (pp. 42-109). Washington, DC: The Brookings Institution.

Frankhauser, S. (1995). Valuing climate change: The economics of the greenhouse. London: Earthscan.

Grozev, O., Alexandrov, V., \& Raev, I. (1996). Vulnerability and adaptation assessments of forest vegetation. In J. B. Smith, N. Bhatti, \& G. V. Menzhulin (Eds.), Adapting to climate change: An international perspective (pp. 374-383). New York, NY: Springer.

Grubb, M. (1996). On the differentiation of quantified emission limitation and reduction objectives (QUELROs) for Annex I countries. In M. Paterson \& M. Grubb (Eds.), Sharing the effort: Analyzing option for differentiating commitments under the framework convention on climate change ( $\mathrm{pp}, 45-60)$. London: The Royal Institute of International Affairs.

Grubb, M. J. (1989). The greenhouse effect: Negotiating targets. London: The Royal Institute of International Affairs.

Heller, T. C. (1996). Environmental realpolitik: Joint implementation and climate change. Indiana Journal of Global Legal Studies, 3(2), 295-340.

Hudec, R. E. (1996). GATT legal restraints on the use of trade measures against foreign environmental practices. In J. Bhagwati \& R. E. Hudec (Eds.), Fair trade and harmonization: Prerequisites for free trade? Volume 2-legal analysis (pp. 95-174). Cambridge, MA: MIT Press.

Inglehart, R. (1995). Public support for environmental protection: Objective problems and subjective values in 43 societies. PS: Political Science and Politics, 28(1), 57-71.

Intergovernmental Panel on Climate Change. (1995). Climate change 1995, IPCC second assessment. New York, NY: Intergovernmental Panel on Climate Change.

International Energy Agency. (1994). Climate change policy initiatives. Volume I: OECD countries. Paris: International Energy Agency.

International Energy Agency. (1995). Energy balances of OECD countries: 1992-1993. Paris: International Energy Agency.

International Energy Agency. (1996a). Climate change policy initiatives. Volume II: $1995 / 96$ update. Selected non-IEA countries. Paris: International Energy Agency.

International Energy Agency. (1996b). Energy statistics and balances of non-OECD countries: 1993-1994. Paris: International Energy Agency.

Kawashima, Y. (1996). The possibility of differentiating targets: Indices and indexing proposals for equity. In M. Paterson \& M. Grubb (Eds.), Sharing the effort: Analyzing option for differentiating commitments under the framework convention on climate change (pp. 6170). London: The Royal Institute of International Affairs.

Keohane, R. O., Haas, P. M., \& Levy, M. A. (1993). The effectiveness of international environmental institutions. In P. M. Haas, R. O. Keohane, \& M. A. Levy (Eds.), Institutions for the earth: Sources of effective international environmental protection (pp. 3-24). Cambridge, MA: MIT Press.

Kramer, P. J., \& Sionit, N. (1987). Effects of increasing carbon dioxide concentration on the physiology and growth of forest trees. In W. E. Shands \& J. S. Hoffman (Eds.), The greenhouse effect, climate change, and U.S. forests (pp. 219-246). Washington, DC: The Conservation Foundation.

Krasner, S. D. (1978). Defending the national interest: Raw materials investments and U.S. foreign policy. Princeton, NJ: Princeton University Press.

Leverenz, J. W., \& Lev, D. J. (1987). Effects of carbon dioxide-induced climate changes on the natural ranges of six major commercial tree species in the western United States. In $W$. E. Shands \& J. S. Hoffman (Eds.), The greenhouse effect, climate change, and U.S. forests (pp. 123-155). Washington, DC: The Conservation Foundation.

Long, S. J. (1997). Regression models for categorical and limited dependent variables. Advanced quantitative techniques in the social sciences, No. 7. Thousand Oaks, CA: Sage.

Maeler, K.-G. (1991). Incentives in international environmental problems. In H. Siebert (Ed.), Environmental scarcity: The international dimension (pp. 75-92). Kiel: Institut fuer Weltwirtschaft an der Universitaet, J.C.B. Mohr, Tuebingen.

Mann, D. E. (1983). Research on political institutions and their response to the problem of an increase in $\mathrm{CO}_{2}$ in the atmosphere. In R. S. Chen, E. Boulding, \& S. H. Schneider (Eds.), Social science research and climate change (pp. 116-145). Holland: Dordrecht.

Mata, L. J. (1996). A study of climate change impacts on the forests of Venezuela. In J. B. Smith, N. Bhatti, \& G. V. Menzhulin (Eds.), Adapting to climate change: An international perspective (pp. 347-358). New York, NY: Springer. 
Matarira, C. H., Mwamuka, F. D., \& Makadho, J. M. (1996). Adaptive measures for Zimbabwe's agricultural sector. In J. B. Smith, N. Bhatti, \& G. V. Menzhulin (Eds.), Adapting to climate change: An international perspective (pp. 128-147). New York, NY: Springer.

Mendelson, R., Morison, W., Schlesinger, M. E., \& Andronova, N. G. (1997). Country-specific market impacts of climate change [On-line]. Available: http://crga.atmos.uiuc.edu/public/ CRG_Publications/Market_Impact/text.htm, 07/18/97.

Milner, H. (1993). Maintaining international commitments in trade policy. In R. K. Weaver \& B. A. Rockman (Eds.), Do institutions matter? Government capabilities in the United States and abroad (pp. 345-369). Washington, DC: The Brookings Institution.

Mitchel, R, B. (1995). Heterogeneities at two levels: States, non-state actors and international oil pollution. In R. O. Keohane \& E. Ostrom (Eds.), Local commons and global interdependence: Heterogeneity and cooperation in two domains (pp. 223-254). London: Sage.

Mizina, S. V., Eserkepova, I. B., Pilifosova, O. V., Dolgih, S. A., \& Gossen, E. F. (1996). Modelbased climate change vulnerability and adaptation assessment for wheat yields in Kazakhstan. In J. B. Smith, N. Bhatti, \& G. V. Menzhulin (Eds.), Adapting to climate change: An international perspective (pp. 148-163). New York, NY: Springer.

Mohr, E. (1991). Global warming: Economic policy in the face of positive and negative spillovers. In H. Siebert (Ed.), Environmental scarcity: The international dimension (pp. 189-212). Kiel: Institut fuer Weltwirtschaft an der Universitaet, J.C.B. Mohr, Tuebingen.

Moore, T. G. (1997). Global warming: A boon to humans and other animals [On-line]. Available: http://www-leland.stanford.edu/ moore/Boon_To_Man.htm, 07/17/97.

Nietze, W. A. (1991). A proposed structure for an international convention on climate change. In World Resource Institute, Greenhouse warming: Negotiating a global regime (pp. 33-36). New York, NY: World Resource Institute.

Nordhaus, W. D. (1991). To slow or not to slow: The economics of the greenhouse effect. The Economic Journal, 10I(July), 920-937.

Oak Ridge National Laboratory. (1997). Carbon dioxide emission estimates from fossil-fuel burning, hydraulic cement production, and gas flaring [On-line]. Available: http://cdiac.ESD.ORNL.GOV/ftp/ndp030r7/emissions-tables/nation94.da07/14/97.

Olson, M. (1965). The logic of collective action: Public goods and the theory of groups. Cambridge, MA: Harvard University Press.

Ostrom, E. (1990). Governing the commons: The evolution of institutions for collective action. Cambridge: Cambridge University Press.

Oye, K. A., \& Maxwell, J. H. (1995). Self-interest and environmental management. In R. O. Keohane \& E. Ostrom (Eds.), Local commons and global interdependence: Heterogeneity and cooperation in two domains (pp. 191-222). London: Sage.

Paterson, M. (1996). Introduction and rapporteur's report of workshop presentations and discussions. In M. Paterson \& M. Grubb (Eds.), Sharing the effort: Analyzing options for differentiating commitments under the framework convention on climate change (pp. 116). London: The Royal Institute of International Affairs.

Reddy, R. K, Hodges, H. F., \& McKinion, J. M. (1995). Cotton crop responses to a changing environment. In C. Rosenzweig, G. A. Peterson, D. M. Kral, \& M. K. Viney (Eds.), Climate change and agriculture: Analysis of potential international impacts (pp. 3-30). Special publication series, No. 59. Madison, Wl: American Society of Agronomy.

Richardson, E. L. (1991). Elements of a framework treaty on climate change. In World Resource Institute, Greenhouse warming: Negotiating a global regime (pp. 25-32). New York, NY: World Resource Institute.

Rose, A. (1992). Equity considerations of tradable carbon emission entitlements. In United Nations Conference on Trade and Development, Combating global warming: Study on a global system of tradable carbon emission entitlements (pp. 55-83). New York, NY: United Nations Conference on Trade and Development.

Rowell, A. (1997). Green backlash: Global subversion of the environmental movement. New York, NY: Routledge.

Russett, B., with the collaboration of W. Antholis, C. R. Ember, M. Ember, \& Z. Maoz. (1993). Grasping the democratic peace: Principles for a post-Cold War world. Princeton, NJ: Princeton University Press.

Sand, P. (Ed.). (1992). The effectiveness of international environmental agreements: A survey of existing legal instruments. United Nations Conference on Environment and Development. Cambridge, MA: Grotius.

Sandenburg, R., Taylor, C., \& Hoffman, J. S. (1987). Rising carbon dioxide, climate change, and forest management: An overview. In W. E. Shands \& J. S. Hoffman (Eds.), The greenhouse effect, climate change, and U.S. forests (pp. 113-121). Washington, DC: The Conservation Foundation.

Sandler, T., \& Sargent, K. (1995). Management of transnational commons: Coordination, publicness, and treaty formation. Land Economics, $71(2), 145$.

Singh, U., \& Padilla, J. L. (1995). Simulating rice response to climate change. In C. Rosenzweig, G. A. Peterson, D. M. Kral, \& M. K. Viney (Eds.), Climate change and agriculture: Analysis of potential international impacts (pp. 99-122). Special publication No. 59. Madison, WI: American Society of Agronomy. 
Sprintz, D., \& Vaahtoranta, T. (1994). The interest based explanation of international environmental policy. International Organization, 48(1), 77-105.

The global warming experiment. (1995). Washington, DC: George Marshall Institute.

Toll, R. S. J. (1995). The climate framework for uncertainty, negotiation, and distribution. In National Center for Atmospheric Research, Final report (pp. 471-496). Boulder, CO: Institute on the Economics of the Climate Resource, Environmental, and Societal Impacts Group, National Center for Atmospheric Research.

Toman, M., \& Bierbaum, R. (1996). An overview of adaptation to climate change. In J. B. Smith, N. Bhatti, \& G. V. Menzhulin (Eds.), Adapting to climate change: An international perspective (pp. 5-15). New York, NY: Springer.

United Nations. (1994). Statistical yearbook. New York, NY: United Nations, Statistical Division.

United Nations. (1996). Statistical yearbook 1994. New York, NY: United Nations.

United Nations, Secretariat to the Framework Convention on Climate Change. (1997). Home page [On-line]. Available: http://www.unfccc.de.

United Nations Framework Convention on Climate Change. (1993). UN Document A/AS.237/18 (part II)/Add. 1. In G. Hoog \& A. Steinmetz (Eds.), International conventions on protection of humanity and environment (pp. 584-606). Berlin: Walter de Gruyter.

Vaughn-Switzer, J. (1997). Green backlash: The history and politics of environmental opposition in the U.S. Boulder, CO: Lynne Rienner.

Vogel, D. (1986). National styles of regulation: Environmental policy in Great Britain and the United States. Ithaca, NY: Cornell University Press.

Vogel, D. (1993). Representing diffuse interests in environmental policymaking. In R. K. Weaver \& B. A. Rockman (Eds.), Do institutions matter? Government capabilities in the United States and abroad (pp. 237-271). Washington, DC: The Brookings Institution.

Waltz, K. N. (1959). Man, the state, and war. New York, NY: Columbia University Press.

Weaver, R. K., \& Rockman, B. A. (1993). Assessing the effects of institutions. In R. K. Weaver \& B. A. Rockman (Eds.), Do institutions matter? Government capabilities in the United States and abroad (pp. 1-41). Washington, DC: The Brookings Institution.

Wirth, T. (1997, July 23). Testimony on climate change, July 15, 1997, before the Subcommittee on Energy and Power. Committee on Commerce. E-mail message from Timothy E. Wirth, global_state@juno.com.

Yandle, B. (1989). The political limits of environmental regulation: Tracking the unicorn. New York, NY: Quorum.

Young, O. R. (1989). International cooperation: Building regimes for natural resources and the environment. Ithaca, NY: Cornell University Press. 


\section{Appendix A \\ Description of the Variables in the Model}

\section{Dependent Variable:}

COMM is an ordinal variable. Values are presented in Table 2.

For the countries that receive international air for the global climate changerelated project, I consider only the projects that are at the stage of implementation or are completed, and not those at proposal stage.

The country is assigned the commitment level it has attained, even though it may not have attained all the lower levels.

Source: Bergesen and Parmann (1996); United Nations, Secretariat to the Framework Convention on Climate Change (1997).

\section{Independent Variables}

AnnexII: Dichotomous variable, with value 1 assigned to the Annex II countries (mainly OECD countries).

Source: International Energy Agency (1996a).

AnnexITR: Dichotomous variable, with value 1 assigned to the Annex I countries, which are considered to be economies in transition.

Source: International Energy Agency (1996a).

GDPPR90: Percentage of 1990 GDP originating from agriculture, forestry, and fishery.

Source: United Nations (1996).

GDP95CAP: GDP per capita, estimates for 1995, measured in Purchasing Power Parities (1000 US \$).

Source: Central Intelligence Agency (1997).

NEXPENER: Dichotomous variable, with value 1 if a country is a net exporter of energy, 0 if net importer.

Source: United Nations (1996).

PARL: Dichotomous variable, with value 1 if the country has parliamentary system.

Source: Europa World Year Book (1997).

EC92cpe: Percentage of country's carbon emissions in the total carbon emissions in 1992.

Source: Oak Ridge National Laboratory (1997).

GDP92CPE: Percentage of a country's GDP in 1992 in total GDP of the world.

Source: United Nations (1996).

TPESCAP: Total primary energy supply per capita (million tons of oil equivalent per capita).

TPES is calculated by IEA as follows: indigenous production + imports exports - international marine bunkers \pm stock exchanges.

Source: International Energy Agency (1995, 1996b). 
Appendix B

Values of the Independent Variables Used in the Probabilities Estimation

\begin{tabular}{lll}
\hline & $\begin{array}{c}\text { Net benefits: low } \\
\text { (high costs, low benefits) }\end{array}$ & $\begin{array}{c}\text { Net Benefits: high } \\
\text { (low costs, high benefits) }\end{array}$ \\
Ability & Costs & Costs \\
Low & nexpener $=1.000$ & nexpener $=0.000$ \\
gdp92cpe $=4.100$ & gdp92cpe $=0.100$ \\
tpescap $=4.700$ & tpescap $=0.100$ \\
parl $=0.000$ & Benefits \\
Benefits & gdp95cap $=16.100$ \\
gdp95cap $=0.740$ & Ability \\
Ability & ec92cpe $=0.100$ \\
ec92cpe $=0.100$ & Costs \\
Ability & Costs & nexpener $=0.000$ \\
High & nexpener $=1.000$ & gdp92cpe $=0.100$ \\
tpescap $=0.100$ \\
gdp92cpe $=4.100$ & parl $=1.000$ \\
tpescap $=4.700$ & Benefits \\
parl $=0.000$ & gdp95cap $=16.100$ \\
Benefits & Ability \\
gdp95cap $=0.740$ & ec92cpe $=3.500$ \\
Ability & \\
ec92cpe $=3.500$ & \\
\hline
\end{tabular}


Appendix C

Predicted Probabilities

Net benefits: low

(high costs, low benefits)

Net Benefits: high

Ability

$\mathrm{PO}=0.0657$

Low

$\mathrm{P} 1=0.0678$

$\mathrm{PO}=7.9 \mathrm{e}-06$

$\mathrm{P} 2=0.1942$

$\mathrm{P} 1=9.4 \mathrm{e}-06$

$\mathrm{P} 3=0.4371$

$\mathrm{P} 2=0.0003$

$\mathrm{P} 4=0.1111$

$\mathrm{P} 3=0.0003$

$\mathrm{P5}=0.1122$

$\mathrm{P} 4=0.0004$

$\mathrm{P} 5=0.0084$

$\mathrm{P} 6=0.0066$

$\mathrm{P} 6=0.0113$

$\mathrm{P} 7=0.0043$

$\mathrm{P7}=0.0814$

$\mathrm{P} 8=0.0007$

$\mathrm{P} 8=0.1918$

$\mathrm{P9}=0.0003$

$\mathrm{P9}=0.7063$

Ability

$\mathrm{P} 0=0.0218$

$\mathrm{P} 0=2.5 \mathrm{e}-06$

High

$\mathrm{P} 1=0.0247$

$\mathrm{P} 1=3.0 \mathrm{e}-06$

$\mathrm{P} 2=0.0872$

$\mathrm{P} 2=0.0001$

$\mathrm{P} 3=0.3735$

$\mathrm{P} 3=0.0001$

$\mathrm{P} 4=0.1836$

$\mathrm{P} 4=0.0001$

$\mathrm{P} 5=0.2726$

$\mathrm{P} 5=0.0027$

P6 $=0.0200$

$\mathrm{P} 6=0.0036$

$\mathrm{P} 7=0.0135$

$\mathrm{P} 7=0.0281$

$\mathrm{P} 8=0.0023$

$\mathrm{P} 8=0.0817$

$P 9=0.0009$

$P 9=0.8837$ 